\title{
Edaphic Invertebrates as Indicators of Soil Integrity Quality
}

\author{
Milena Gedoz ${ }^{1}$ \\ Elisete Maria Freitas ${ }^{1}[$ \\ Vinícius Leão da Silva ${ }^{1}$ (D) \\ Liana Johann ${ }^{1}$ (C)
}

\begin{abstract}
Bioindicator organisms, such as edaphic invertebrates, are constantly used to assess disturbance, as they exhibit responses such as reduced community and changes in diversity, affecting the local ecosystem. The aim of this study was to compare the impacts of disturbance on the edaphic invertebrate community in both a pasture area and a native forest area, during summer and winter. Samplings were conducted for nine days using pitfalls. Bray-Curtis analyses, NMDS, ANOSIM, and SIMPER were applied. There was difference in richness and diversity between areas and seasons. Native forest pitfalls had higher similarity in abundance and diversity in both seasons than pasture pitfalls. Specimens belonging to 20 orders were collected; of those, Collembola, Hymenoptera, Diptera, and Hemiptera had the highest number of individuals. Seasonal influence on the organisms was evident. The impact on edaphic invertebrate community located in the pasture area showed that native forest has higher complexity and structural stability.
\end{abstract}

Keywords: Atlantic Forest, bioindicators, edaphic arthropods, impacted area, pasture.

\section{INTRODUCTION}

Forest exploitation has been always connected to the development of human populations. However, due to continuous suppression and unplanned activities, significant reductions have been observed in forested areas worldwide (Ferreira \& Santos, 2012; Garcia et al., 2018). Forest preservation and sustainable management are of utmost importance to maintain ecosystem balance, as excessive exploitation have negative consequences such as changes in local microclimate, reduced size of populations, loss of genetic variability, and species suppression (Lopes et al., 2017). Several areas with vegetation suppression are used for cattle grazing, affecting soil and local fauna and flora (Coutinho et al., 2017).

Changes in the fauna of impacted sites might be evaluated by analyzing communities of bioindicator organisms. The role played by these organisms is highly connected to environmental conditions, responding to physical, chemical, and structural changes in the environment (Spiller et al., 2018; Rocha et al., 2015; Candido et al., 2012; Mcgeoch, 1998). Arthropoda include several organisms that might be used as bioindicators. These organisms have an important relationship with the soil, and are responsible for several functional processes in an ecosystem, as they occupy a wide array of levels in the trophic chain (Menta \& Remelli, 2020). They also play a role in organic matter degradation, nutrient cycling, and are source of food for other animals, pollinators, seed dispersers, parasites, predators, and herbivores (Copatti \& Gasparetto, 2012; Rosenberg et al., 1986).

Depending on soil use, management, and on the impacts generated, edaphic invertebrate population dynamics might be affected, with decrease in community abundance and richness, thus facilitating the appearance of opportunistic, exotic species adapted to impacted sites. These species, in turn, might cause native organisms to disappear, thus affecting the local system (Gonçalves et al., 2014; Lavelle, 1996; Rosenberg et al., 1986). As these organisms have a high number of species, are largely distributed in several habitats, are found in large amounts, and are easy to sample, they are constantly used as bioindicators (Azevedo et al., 2011; Rosenberg et al., 1986; Santos et al., 2016; Silveira Neto et al., 1995).

Organisms belonging to the orders Orthoptera, Hemiptera, Diptera, Lepidoptera, Hymenoptera, and Coleoptera are important bioindicators, since these orders are comprised of 
subgroups that are adapted to different disturbance regimes, such as increased number of invasive plants, inhibition of decomposition, pollution levels, and reduced number of predators (Wink et al., 2005; Brown, 1997). Other groups, such as Acari, are sensitive to moisture content, $\mathrm{pH}$, soil organic matter, use of insecticides, and agricultural practices (Spiller et al., 2018; Socarrás, 2013). Collembola are closely related with temperature and humidity, and their response lead to several changes, such as changes in soil organic matter, $\mathrm{pH}$, and contamination by heavy metals and pesticides (Spiller et al., 2018; Socarrás, 2013; Pompeo et al., 2016(b); Antoniolli et al., 2013).

Considering the importance of this topic, the aims of the present study were to observe the composition of the edaphic invertebrate community at the order level both in an area exposed to environmental impacts and in a forest area with no direct exposure to anthropogenic action during winter and summer. The assumption was that there would be (1) low species diversity and low abundance of individuals comprising the edaphic invertebrate community in the pasture area with cattle grazing and high species diversity and high abundance of individuals in the preserved native forest area; and (2) increase in these parameters during summer, regardless of the study area.

\section{MATERIAL AND METHODS}

\subsection{Study area}

The present study was conducted in two areas: native forest and pasture, with $500 \mathrm{~m}$ distance between sites (Figure 1). The forest area (F) is located on a hill belonging to Serra de São Vendelino (São Vendelino Mountain Range), with 97 ha $\left(29^{\circ} 19^{\prime} 22.8^{\prime \prime} \mathrm{S}, 51^{\circ} 26^{\prime} 52.8^{\prime \prime} \mathrm{W}\right)$ and forest vegetation at intermediate and advanced regeneration stages. The pasture area $(\mathrm{P})$ used to be predominantly occupied by Axonopus sp. with occurrence of Trifolim sp. and other herbaceous species, and this site has been used for agropastoral activities for nearly 100 years $\left(29^{\circ} 19^{\prime} 17.65^{\prime \prime}\right.$, $\left.51^{\circ} 26^{\prime} 35.22^{\prime \prime} \mathrm{W}\right)$. Both sites are located in Santo Antônio de Santa Clara Baixa, municipality of Carlos Barbosa, Rio Grande do Sul.

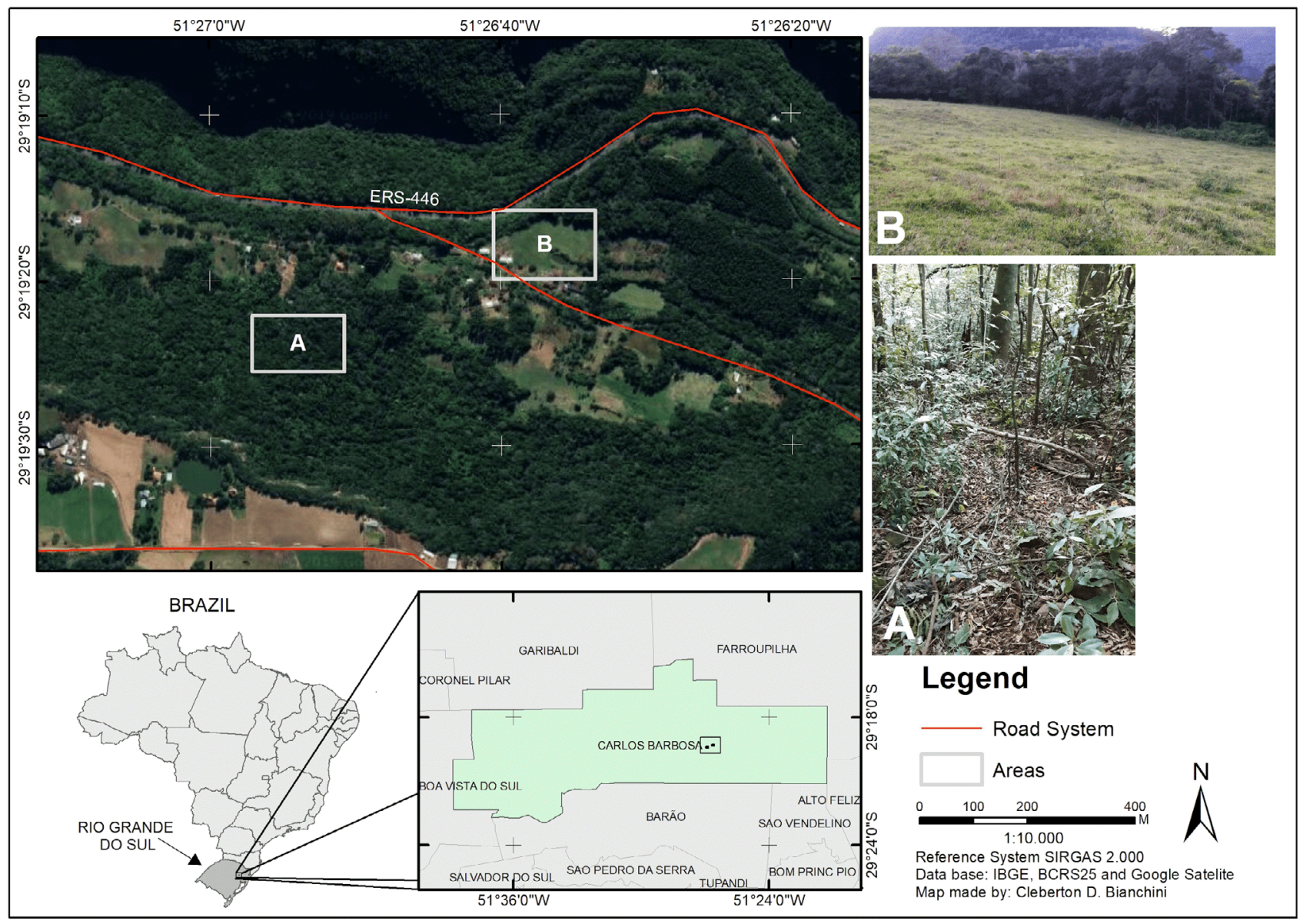

Figure 1. Location of the study areas in the municipality of Carlos Barbosa, Rio Grande do Sul, Brazil, with details of the sampling sites. 
Regional vegetation is an ecotone zone between Deciduous Seasonal Forest and Mixed Ombrophilous Forest formations (IBGE, 2012). Soil is classified as clayish-sandy and is inserted in the Serra Geral Formation and Botucatu Formation (Streck et al., 2002). The municipality is situated 678 a.s.l, its climate is Cfb type, with no dry season and a warm summer (Município de Carlos Barbosa, 2019; Peel et al., 2007). The forest area borders with residences, agricultural crops, and pastures, and is close to ERS-446 road in its lower border. Despite its proximity to areas with anthropogenic occupation, the study forest is well preserved due to the presence of rocky outcrops in the upper part of the hill and because of its location in Serra de São Vendelino. The pasture area also borders with residences, and has a forest fragment at an intermediate regeneration stage, a eucalyptus plantation, agricultural crops, and a dam. It is also situated $90 \mathrm{~m}$ from ERS-446 road.

\subsection{Characterization of each study area}

Mean temperature, air humidity, and luminosity were obtained using a digital hygro-thermo-anemometer-light meter during the sampling period at each sampling point in both areas. Mean plant litter thickness, on the other hand, was obtained while pitfalls were installed using a measuring tape at a distance of $1.0 \mathrm{~m}$ from each pitfall in four opposing directions.

\subsection{Sampling}

Samplings were performed during summer (S) (January/ February) and winter (W) (June) 2019 at both sites (F and P), encompassing a sampling area of $2,400 \mathrm{~m}^{2}$ at each site, by distributing pitfalls every $10 \mathrm{~m}$ across three $40 \mathrm{~m}$ length transects, with a $20 \mathrm{~m}$ spacing between them. The pitfalls were comprised of flasks with a $500 \mathrm{~mL}$ capacity, to which $300 \mathrm{~mL}$ of water and ten drops of neutral detergent were added to immobilize the individuals.

Pitfalls were on site for nine days, collecting edaphic invertebrates that fell into the traps, with maintenance every two days. Captured organisms were screened, quantified, fixed at $70 \%$ alcohol, and identified to the Order level, using a stereoscope microscope and classification keys (Triplehorn \& Johnson, 2013). After data survey, the organisms were deposited at the scientific collection of Museu de Ciências Univates (MCN).

\subsection{Data analysis}

The richness and diversity of organisms were demonstrated by a matrix containing all terrestrial arthropod groups found in all samplings and the total individuals collected per group at each site and during each season. A binary matrix was constructed, represented by order abundance at each site and during $\mathrm{W}$ and $\mathrm{S}$, for an analysis of similarities of edaphic invertebrate composition at both study sites ( $\mathrm{P}$ and $\mathrm{F} \times \mathrm{S}$ and W). A Bray-Curtis analysis of similarity was performed using the statistical program Paleontological Statistics - PAST version 3.0 (Hammer et al., 2001) to check graphically the proximity and separation of sampling units (SU) in clusters.

Ordination of forest and pasture pitfalls was performed based on abundance and diversity of edaphic invertebrate orders using a non-metric multidimensional scaling analysis (NMDS). These data were used in a Bray-Curtis similarity matrix. In order to check whether there was significant difference in arthropod community composition between environments ( $\mathrm{F}$ and $\mathrm{P}$ ) and seasons ( $\mathrm{S}$ and $\mathrm{W}$ ), an analysis of similarity (ANOSIM) was performed with a limit of 999 permutations.

An analysis of similarity percentage (SIMPER) was performed to identify which orders contributed the most with the similarity between pitfalls in $\mathrm{F}$ and $\mathrm{P}$ (W and $\mathrm{S}$ ), as well as the dissimilarity between them in the different clusters of the NMDS ordination. Ordination analyses, NMDS, ANOSIM, and SIMPER were performed using PRIMER-E (Clarke \& Gorley, 2002) version 5.2.9.

\section{RESULTS AND DISCUSSION}

The pasture area had higher luminosity, lower humidity, and higher mean temperature than the forest area during both seasons of the year (Table 1). On the other hand, the forest area had higher mean plant litter thickness during both sampling seasons.

Table 1. Mean value of environmental parameters evaluated in all pitfalls and samplings performed at two sites (pasture and forest) during two seasons of the year (summer and winter) in the municipality of Carlos Barbosa, Rio Grande do Sul, Brazil.

\begin{tabular}{|ccccc|} 
Parameters & $\begin{array}{c}\text { Forest } \\
\text { Summer }\end{array}$ & $\begin{array}{c}\text { Forest } \\
\text { Winter }\end{array}$ & $\begin{array}{c}\text { Pasture } \\
\text { Summer }\end{array}$ & $\begin{array}{c}\text { Pasture } \\
\text { Winter }\end{array}$ \\
\hline Luminosity (lux) & 178.43 & 123.42 & 6,500 & 4,928 \\
\hline Humidity & 68.12 & 73.68 & 62.08 & 70.74 \\
\hline Temperature $\left(C^{\circ}\right)$ & 27.26 & 22.98 & 29.22 & 23.2 \\
\hline Plant Litter $(\mathrm{cm})$ & 2.05 & 1.68 & 0.05 & 0.05 \\
\hline
\end{tabular}

A total of 19,358 individuals were collected in the samplings during summer and winter, belonging to 20 orders (Table 2). A total of 12,354 individuals were captured during summer, of which 1,783 (14.4\%) were collected from pasture, belonging to 12 orders, with high abundance of Hymenoptera, Collembola, and Hemiptera. In the forest, on the other hand, 10,571 $(85.6 \%)$ organisms were collected belonging to 19 orders, of 
which Collembola, Hymenoptera, and Diptera were the most abundant. During winter, 7,004 individuals were collected (of which 3,407 (48.6\%) derived from pasture), belonging to 14 orders, while 3,597 (51.4\%) individuals were collected in the forest, belonging to 16 orders. The orders with the highest number of specimens at both sites were Collembola, Hymenoptera, and Diptera. A peculiarity observed in the Hymenoptera group was the fact that ants were the most frequently collected individuals. According to Machado et al. (2015), Formicidae predominates, with high abundance in the majority of terrestrial ecosystems, especially tropical forests. This group was also considered the most abundant in studies conducted in the Atlantic Forest (Menezes et al., 2009). Hemiptera was also differentiated since most of its individuals were found in the larval phase.

Table 2. List of edaphic invertebrate orders and total individuals collected from pasture and forest during two seasons (summer and winter) in the municipality of Carlos Barbosa, Rio Grande do Sul, Brazil.

\begin{tabular}{|c|c|c|c|c|}
\hline & \multicolumn{2}{|c|}{ Summer } & \multicolumn{2}{|c|}{ Winter } \\
\hline Order & Forest & Pasture & Forest & Pasture \\
\hline Acari & 136 & 63 & 79 & 218 \\
\hline Araneae & 146 & 119 & 80 & 159 \\
\hline Blattodea & 4 & 1 & 3 & 2 \\
\hline Coleoptera & 442 & 130 & 155 & 191 \\
\hline Collembola & 8032 & 320 & 2324 & 1109 \\
\hline Decapoda & 22 & 0 & 21 & 0 \\
\hline Dermaptera & 6 & 1 & 0 & 0 \\
\hline Diplopoda & 17 & 0 & 18 & 15 \\
\hline Diptera & 728 & 102 & 407 & 448 \\
\hline Gastropoda & 2 & 0 & 7 & 5 \\
\hline Hemiptera & 21 & 169 & 28 & 248 \\
\hline Hirudinea & 3 & 0 & 0 & 0 \\
\hline Hymenoptera & 829 & 839 & 444 & 977 \\
\hline Isopoda & 118 & 16 & 21 & 10 \\
\hline Lepidoptera & 2 & 0 & 1 & 0 \\
\hline Neuroptera & 2 & 0 & 0 & 0 \\
\hline Odonata & 0 & 4 & 0 & 0 \\
\hline Oligochaeta & 13 & 0 & 2 & 1 \\
\hline Orthoptera & 42 & 19 & 5 & 15 \\
\hline Thysanoptera & 6 & 0 & 2 & 9 \\
\hline Total & 10,571 & 1,783 & 3,597 & 3,407 \\
\hline
\end{tabular}

Collembola was the order with the highest number of individuals in all samplings performed at both sites. In more developed soils, this group plays an important role in the degradation of plant litter and of other organic matter found in the soil, constantly releasing nutrients into the environment (Rzeszowski et al., 2017; Kitching et al., 2020; Rusek, 1998). According to Brown (1997), Collembola has reduced diversity in environments with strong sunlight and high disturbance; on the other hand, in environments with moderate disturbance, there are shifts in species composition in the impacted area. Brown (1997) and Thakur et al. (2018) consider soil humidity and organic matter to be the environmental factors that cause the highest variations in these individuals. The high amount of individuals collected indicated a positive relationship with organic matter found in the environment, since the highest levels of plant litter, and consequently, the highest amount of food were found in the forest. Lower humidity during summer compared to winter is one of the factors that might have caused the lower density of individuals during summer and their higher density during winter.

The second most abundant group was Hymenoptera. The high presence of ants in impacted areas is due to increased food availability and decreased number of predators (Freitas et al., 2006), which are factors that might explain the results obtained in the present study; the number of Hymenoptera specimens collected from pasture was similar to or higher than those collected in the forest area. A study conducted by Oliveira Filho et al. (2014) in different months of the year in a remnant of the Seasonal Semideciduous Forest and a pasture that was inactive for two years showed differences in richness of taxonomic groups between areas and seasons. These authors found higher richness during the season with high temperatures (February) and lower richness in the coldest month (May), with a total of 19 taxa and predominance of Collembola and Formicidae in both areas and seasons. This pattern is similar to the observed in the present study, with the same seasonal variation in communities, presence of 20 taxa, and some of the same predominant orders.

The lower arthropod richness observed in pasture areas inside the Atlantic Forest is in accordance with results found in literature (Amazonas et al., 2018; Cunha \& Orlando, 2011; Ferreira et al., 2017; Martins et al., 2011; Moço et al., 2005; Silva et al., 2016). According to these authors, forest areas have an extensive structural complexity of plant communities, thus providing high variety of niches and food sources that benefit edaphic invertebrate communities, which explains the high richness levels in forest compared to the reduced vegetation found in pasture areas.

\subsection{Analysis of similarity between samplings}

The Bray-Curtis Similarity cluster analysis showed that the cofenetic value was 0.848 , indicating high differentiation 
between environments ( $\mathrm{P}$ and $\mathrm{F}$ ) and seasons ( $\mathrm{S}$ and $\mathrm{W}$ ). Overall, the differentiation between the groupings observed in the Cluster occurred due to the high number of Collembola individuals collected. The two first groups (A and B) (Figure 2) showed similarity of $36 \%$ and differed in number of Collembola individuals.

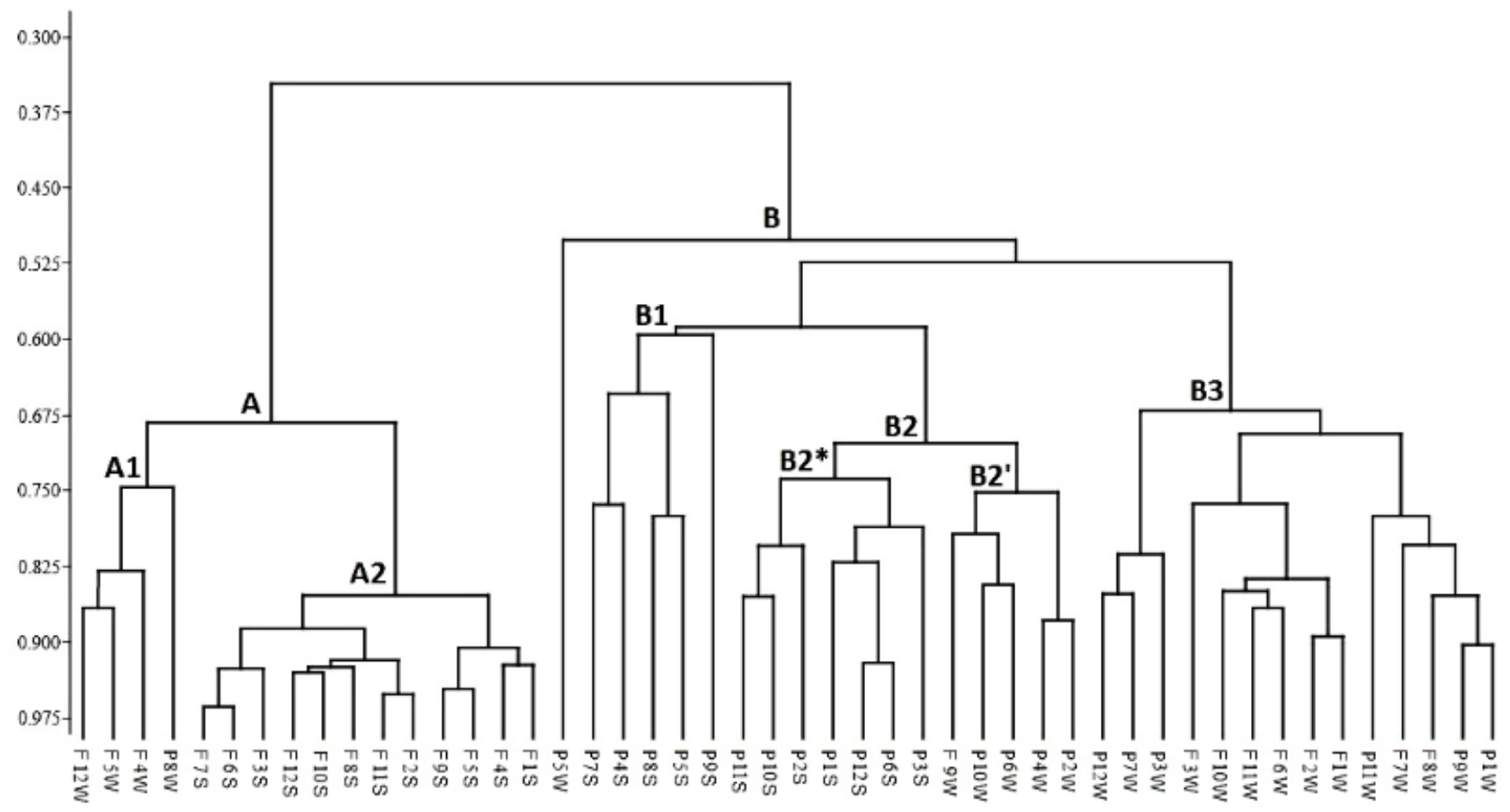

Figure 2. Bray-Curtis similarity with all sampling points per area (Pasture - P and Forest - F) and per season (Summer - S and Winter - W) in forest and pasture in the municipality of Carlos Barbosa, Rio Grande do Sul, Brazil.

The pitfalls with the highest Collembola values at all sites and seasons were grouped in A, and these SU's had a $68 \%$ similarity in abundance and diversity. FW pitfalls and one PW pitfall were grouped in A1, whence the highest amounts of Collembola were collected at both sites during winter. PW pitfall found in A1 was segregated from the other PWs, as it had the highest Collembola value (268).

A2 grouping was comprised of FS pitfalls, indicating that pitfalls in this sampling had high similarity in abundance and diversity, and they all were differentiated from winter samplings. A2 pitfalls had the highest number of organisms and the highest diversity of taxonomic groups collected, especially Collembola, compared to all the other sites and seasons. $\mathrm{A} 1$ and $\mathrm{A} 2$ were differentiated due to these factors, as A2 had the highest Collembola values in all samplings.

Group B, on the other hand, was comprised of B1, B2, and B3, which had a similarity of $50 \%$ and were comprised of sampling points PS, PW, and FW. Prior to this division, an outlier appeared, comprised of a PW pitfall. This isolated value was due to the high number of Hymenoptera individuals collected (247), differing from the other sampling points and seasons. This result might have occurred due to an incidental population displacement. Another plausible reason could be that the pitfall was installed near a nest. However, this hypothesis is not valid because the high number of individuals occurred only one day during the winter sampling period.

Groupings B1 and B2 had higher similarity to each other (58\%) than to B3 (53\%). Group B1 was comprised only of PS pitfalls and was separated from $B 2$ because it had a lower number of individuals collected by pitfall (min. 77 and max. 105 individuals) compared to B2 (min. 159 and max. 269 individuals). Grouping B2 was comprised of PS and PW pitfalls, and one FW pitfall. A subdivision of B2, with 70\% of similarity, was explained by the difference in diversity between groupings - B2*, with 11 orders, and B2', with 15 orders - and the presence of one FW, which was not placed together with the other FW pitfalls in grouping B3, as it had a lower Collembola value.

Grouping B3 had a $68 \%$ similarity and was comprised of FW and PW pitfalls, which were differentiated from B1 and B2 as they had the highest Collembola values in B. No PS pitfalls were included in B3 due to the differences found in groups between seasons. Thysanoptera individuals were 
recorded, Gastropoda and Diplopoda were absent, and there was reduced amount of Diptera and Acari in summer pitfalls.

The NMDS analysis ordinated the 48 SU's. The "disturbance" value provided by the scaling (Stress value $=0.06$ ) indicated significant ordination for the graphic representation (Figure 3). There was an evident separation between pasture sampling points and those in the forest. Forest SU's during summer and forest SU's during winter also had a distance between them, indicating difference in abundance and diversity of organisms collected from the pitfalls between seasons. Forest SU's during summer were closely grouped, indicating high similarity in abundance and diversity of organisms collected from each pitfall, as opposed to pasture, where there was dispersal between sampling seasons and SU's, suggesting a difference between pitfalls and seasons for these variables.

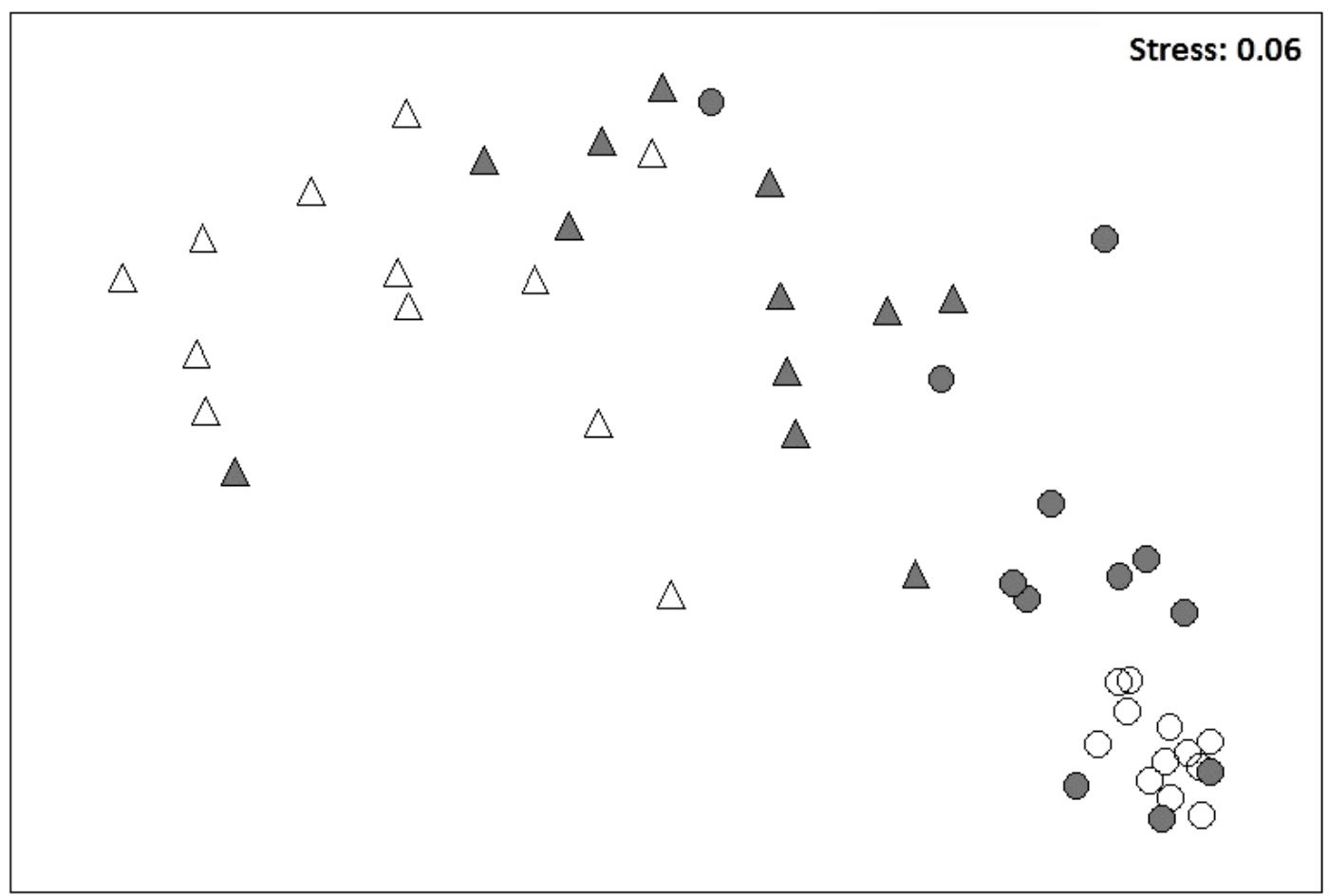

Subtitle: $\triangle$ summer pasture $O$ summer forest $\Delta$ winter pasture $O$ winter forest

Figure 3. Relationship between abundance and diversity in the 48 pitfalls in both environments, pasture and forest, in samplings during the summer and winter of 2019, in the municipality of Carlos Barbosa, Rio Grande do Sul, Brazil.

NMDS results corroborate the ANOSIM analysis (global $\mathrm{R}=0.553 ; \mathrm{p}=0.001$ ), which showed a significant different between edaphic invertebrate communities at both sites and during both seasons. Based on ANOSIM results, comparisons between both environments and seasons were observed to be different; PS $x$ FS ( $\mathrm{R}=0.990 ; \mathrm{p}=0.001)$, PS $\times \mathrm{PW}$ $(\mathrm{R}=0.369 ; \mathrm{p}=0.001), \mathrm{FS} \times \mathrm{FW}(\mathrm{R}=0.326 ; \mathrm{p}=0.001)$, and PW $x$ FW $(\mathrm{R}=0.528 ; \mathrm{p}=0.001)$.

Canopy density is a factor that affects edaphic fauna. A higher diversity of organisms is found at sites with more developed canopy, due to the microclimate caused by shading of trees (Sabrina et al., 2009; Sarlo, 2006; Pompeo et al., 2016(a)). Additionally, the lower vegetation structure observed in pasture areas causes higher variations in microclimatic conditions, both in temperature and soil humidity, rendering them unfavorable for edaphic invertebrate communities, affecting the occurrence of certain groups that might increase depending on the season (Martins et al., 2011; Decaëns et al., 2004; Pompeo et al., 2016(a)).

Degraded tropical areas expose edaphic fauna to a highly stressful environment, with compacted soils, which are poor in nutrients, and unstable temperature and humidity; communities respond to these impacts by reducing their diversity and density (Amazonas et al., 2018) and this disturbance might have probably affected the communities of the pasture area evaluated.

SIMPER analysis showed a $67 \%$ similarity among 12 PS pitfalls analyzed. Hymenoptera was the major order responsible for this similarity, with approximately (ca.) $45 \%$, followed by 
Collembola (ca. 18\%) and Hemiptera (ca. 9\%). Evaluating PW pitfalls, a similarity of $68 \%$ was observed between sampling points, and this similarity resulted primarily from Collembola (ca. 30\%), Hymenoptera (ca. 27\%), and Diptera (17\%).

Similarity among FS pitfalls was $88.6 \%$, with orders Collembola (ca. 79\%), accounted primarily by Hymenoptera (ca. 8\%), and Diptera (ca. 6\%). In FW pitfalls, on the other hand, the similarity resulting from the analysis was $66 \%$, which was explained by Collembola (ca. 59\%), Diptera (ca. 15\%), and Hymenoptera (ca. 13\%).

SIMPER analysis showed that the difference between PS pitfalls and FS pitfalls was $77.5 \%$, and Collembola was the main responsible for the difference in the community (ca. 80\%), followed by Diptera (ca. 6.5\%) and Hymenoptera (ca. 4\%). The dissimilarity found between PW x FW was $41 \%$, and the orders responsible for this difference were Collembola (ca. 49\%), Hymenoptera (ca. 21.5\%), and Hemiptera (ca. 8\%).

SIMPER analysis showed a $43 \%$ difference between SU's of PS x PW, with Collembola (ca. 33\%), Hymenoptera (26\%), and Diptera (16\%) responsible for the differentiation among pitfalls. There was a $52 \%$ dissimilarity between FS x FW pitfalls, and Collembola (ca. 80\%), followed by Hymenoptera (ca. 6\%) and Diptera (5\%), were mostly responsible for this difference.

The most important groups, with the highest influence in the results, were Collembola, Hymenoptera, Diptera, and Hemiptera. Maestri et al. (2013) found similar orders in a study conducted in a transition forest between Mixed Ombrophilous Forest and Plateau Fields, where Hymenoptera and Collembola were the orders with the highest abundance. Amazonas et al. (2018) found that Hymenoptera was the most abundant order in the Seasonal Semideciduous Forest and in a pasture with predominance of Urochloa sp.

According to Brown (1997) and Arcoverde et al. (2017), there is high variation in Hymenoptera diversity: there is possibly no shift, decrease, or increase in Hymenoptera species at sites with low impact; changes in species composition or reduced Hymenoptera species in environments with moderate impact; and decreased Hymenoptera species in highly impacted environments; owing to the fact that this is a highly diversified group. Humidity, plant diversity, mutualism, and amount of prey are factors that account for these variations (Brown, 1997).

According to Brown (1997), Diptera responds with increased diversity to environments with low and moderate impact, and there is either no effect or no species turnover in highly impacted environments; the major factors responsible for these variations are humidity, plant diversity, structure, heterogeneity, and amount of organic matter in the soil.
Souto et al. (2008) indicated that Diptera probably has higher resistance to seasonal climate variations, and is thus considered a dominant order.

Hemiptera is comprised of predatory and herbivore organisms, and increased diversity is observed in slightly and moderately impacted environments; on the other hand, decreased diversity is observed in highly impacted environments, and is related with plant diversity, mutualism, and prey availability (Brown, 1997; Gerlach et al., 2013). This was one of the major groups responsible for the similarity among SU's. However, most individuals collected in both areas were in the larval phase.

FS and FW samplings were significantly different, which indicates seasonal influence on edaphic invertebrate community. SU's in FW and FS had high similarity in abundance and diversity of organisms collected from the pitfalls. Regarding pasture, PS and PW were significantly different from each other and were significantly different from FS and FW samplings, indicating seasonal influence and differentiation between sampling sites. Higher differences in abundance and diversity of organisms were observed between PS and PW SU's, related to pitfalls within and between seasons. Compared to data obtained in forest SU's, forest proves to be an environment with higher integrity than pasture. According to Hooper et al. (2005), who compared forest and pasture areas, the highest richness values observed in forest indicated higher complexity of ecological ecosystem functioning and higher structural stability in this environment.

Reduced biodiversity results in changes in ecological functions, such as loss of self-regulation capacity, reduced genetic variability, population imbalances, and imbalances in the relationships between different groups, which affect the environment (Lopes et al., 2017; Nicholls \& Altieri, 2007; Cardinale et al., 2012; Peñalver-Cruz et al., 2019). Therefore, the study of edaphic invertebrates is a very important tool in the preservation and sustainable management of the ecosystem, in order to maintain the integrity of native forest areas and help areas under recovery, taking advantage of the interrelations with soil and vegetation provided by edaphic invertebrates (Rodrigues et al., 2016).

\section{CONCLUSIONS}

Based on diversity and abundance of organisms, there were significant differences between forest and pasture areas, although the orders with the highest abundance were the same in both areas (Collembola, Hymenoptera, Diptera, and Hemiptera). These results corroborate the hypothesis that there would be higher diversity and abundance in native forest than in pasture. 
A seasonal influence on edaphic invertebrate community was identified, with significant differences related to diversity and abundance, which decreased during winter. Regarding this variable, the second hypothesis (that parameters would increase during summer in both areas) was partially confirmed, as although there were increased results in forest during summer, there was higher abundance and diversity in pasture during winter.

Native forest area showed to be an environment with higher integrity, represented by the similarity between pitfall samplings, higher abundance, and higher diversity of organisms compared to pasture. Therefore, it was evident that the impacted area had a negative effect on edaphic invertebrate community in this study.

In face of the results obtained, it is clearly possible to follow pasture area recovery by monitoring edaphic invertebrates and detecting the most important groups in this process, thus aiding the choice of techniques that benefit these organisms in the recovery of degraded areas.

\section{SUBMISSION STATUS}

Received: 09 Aug. 2020

Accepted: 08 Dec. 2020

Associate editor: Rodrigo Studart Corrêa

\section{CORRESPONDENCE TO}

Milena Gedoz

Universidade do Vale do Taquari, Av. Avelino Talini, 171, CEP 95914-014, Lajeado, RS, Brasil

e-mail: milena.ged@gmail.com

\section{REFERENCES}

Amazonas NT, Vianib RAG, Regob MGA, Camargoc FF, Fujiharab RT, Valsechib OA. Soil macrofauna density and diversity across a chronosequence of tropical forest restoration in Southeastern Brazil. Brazilian Journal of Biology 2018; 78(3): 449-459. 10.1590/ 1519-6984.169014

Antoniolli ZI, Redin M, Souza EL, Pocojeski E. Metais pesados, agrotóxicos e combustíveis: efeito na população de colêmbolos no solo. Ciência Rural 2013; 43(6): 992-998. 10.1590/S010384782013005000056

Arcoverde GB, Andersen AN, Setterfield SA. Is livestock grazing compatible with biodiversity conservation? Impacts on savanna ant communities in the Australian seasonal tropics. Biodivers. Conserv. 2017; 26: 883-897. 10.1007/s10531-016-1277-5

Azevedo FR, Moura MAR, Arrais MSB, Nere DR. Composição da entomofauna da Floresta Nacional do Araripe em diferentes vegetações e estações do ano. Ceres 2011; 58(6): 740-748. 10.1590/ S0034-737X2011000600010

Brown KS. Diversity, disturbance, and sustainable use of Neotropical forests: insects as indicators for conservation monitoring. Journal of Insect Conservation 1997; 1(1): 25-42. 10.1023/A:1018422807610
Candido AKAA, Silva NM, Barbosa DS, Farias LN, Souza WP. Fauna edáfica como bioindicadores de qualidade ambiental na nascente do rio São Lourenço, Campo Verde - MT, Brasil. Engenharia Ambiental 2012; 9(1): 67-82.

Cardinale BJ, Duffy JE, Gonzalez A, Hooper DU, Perrings C, Venail P, et al. Biodiversity loss and its impact on humanity. Nature 2012; 486: 59-67. 10.1038/nature11148

Clarke KR, Gorley RN. PRIMER-E for Windows. Version 5.2.9. Plymouth: PRIMER-e; 2002.

Copatti CE, Gasparetto FM. Diversidade de insetos em diferentes tipos de borda em um fragmento de Floresta Ombrófila Mista. Revista Biociências 2012; 18(2): 32-40.

Coutinho FS, Pereira MG, Menezes CEG, Guareschi RF, Assunção SA. Atributos edáficos em áreas de agricultura, pastagem e três estágios sucessionais de floresta. Floresta e Ambiente 2017; 24: 1-11. $10.1590 / 2179-8087.091914$

Cunha HF, Orlando TYS. Functional composition of termite species in areas of abandoned pasture and in secondary succession of the Parque Estadual Altamiro de Moura Pacheco, Goiás, Brazil. Bioscience Journal 2011; 27(6): 986-992.

Decaëns T, Jiménez JJ, Barros E, Chauvel A, Blanchart E, Fragoso $\mathrm{C}$, et al. Soil macrofaunal communities in permanent pastures derived from tropical forest or savana. Agriculture, Ecosystems and Environment 2004; 103(2): 301-312. 10.1016/j.agee.2003.12.005

Ferreira CR, Souza RC, Correia MEF, Resende AS, Anjos LHC, Pereira MG. Edaphic arthropods in different successional stages of Atlantic forest and abandoned pasture areas. Comunicata Scientiae 2017; 8(2): 296-306. 10.14295/cs.v8i2.1750

Ferreira RA, Santos PL. Direct sowing: an alternative to the restoration of ecosystems of tropical forests. Tropical Forests 2012; 333-348. 10.5772/30771

Freitas AVL, Leal IR, Uehara-Prado M, Iannuzzi L. Insetos como indicadores de conservação da paisagem. In: Rocha CFD, Bergalo HG, Sluys MV, Alves MAS, editors. Biologia da Conservação: essências. São Carlos: Rima; 2006.

Garcia JM, Longo RM, Penereiro JC, Mendes DR, Mantovani P. Uso de fotografias hemisféricas para avaliação da qualidade ambiental na mata de Santa Genebra, Campinas-SP, Brasil. Ciência Florestal 2018; 28(1): 175-190. 10.5902/1980509831651

Gerlach J, Samways M, Pryke J. Terrestrial invertebrates as bioindicators: an overview of available taxonomic groups. Journal of Insect Conservation 2013; 17(4): 831-850. 10.1007/s10841-013-9565-9

Gonçalves IS, Carneiro TR, Viana PA. Levantamento de coleópteros em mata nativa e na cultura do milho. Ciências Exatas e da Terra e Ciências Agrárias 2014; 9(2): 73-79.

Hammer MF, Karafet TM, Redd AJ, Jarjanazi H, SantachiaraBenerecetti S, Soodyall H, et al. Hierarchical patterns of global human y-chromosome diversity. Molecular Biology and Evolution Society 2001; 18(7): 1189-1203. 10.1093/oxfordjournals.molbev.a003906

Hooper DU, Chapin III FS, Ewel JJ, Hector A, Inchausti P, Lavorel S, et al. Effects of biodiversity on ecosystem functioning: a consensus of current knowledge. Ecological Monographs 2005; 75(1): 3-35. 10.1890/04-0922 
Instituto Brasileiro de Geografia e Estatística [IBGE]. Manual técnico da vegetação brasileira. Rio de Janeiro: IBGE; 2012.

Kitching RL, Dahlsjö CAL, Eggleton P. Invertebrates and the complexity of tropical ecosystems. Biotropica 2020; 52: 207-214. 10.1111/btp. 12768

Lavelle P. Diversity of soil fauna and ecosystem function. Biology International 1996; 33: 3-16.

Lopes AS, Soares S, Silva EM, Roel AR. Diversidade de insetos e aranhas presentes em diferentes fisionomias no Pantanal, na seca e cheia, Corumbá, MS. Multitemas 2017; 22(51): 127-154. 10.20435/ multi.v22i51.1422

Machado DL, Pereira MG, Correia MEF, Diniz AR, Menezes CEG. Soil fauna in successional dynamics of Atlantic Forest in semideciduous seasonal forest in the basin of river 'Paraíba do Sul', Rio de Janeiro State. Ciência Florestal 2015; 25(1): 91-106. 10.1590/1980-509820152505091

Maestri R, Leite MAS, Schmitt LZ, Restello RM. Efeito de mata nativa e bosque de eucalipto sobre a riqueza de artrópodos na serapilheira. Perspectiva 2013; 37: 31-40.

Martins L, Almeida FS, Mayhé-Nunes AJ, Vargas AB. Efeito da complexidade estrutural do ambiente sobre as comunidades de formigas (Hymenoptera: Formicidae) no município de Resende, RJ, Brasil. Revista Brasileira de Biociências 2011; 9(2): 174-179.

Mcgeoch MA. The selection, testing and application of terrestrial insects as bioindicators. Biological Reviews 1998; 73(2): 181-201. 10.1111/j.1469-185X.1997.tb00029.x

Menezes CEG, Correia MEF, Pereira MG, Batista I, Rodrigues KM, Couto WH, et al. Macrofauna edáfica em estádios sucessionais de Floresta Estacional Semidecidual e pastagem mista em Pinheiral (RJ). Revista Brasileira de Ciência do Solo 2009; 33(6): 1647-1656. 10.1590/S0100-06832009000600013

Menta C, Remelli S. Soil Health and Arthropods: From Complex System to Worthwhile Investigation. Insects 2020; 11(54): 1-23. $10.3390 /$ insects 11010054

Moço MKS, Gama-Rodrigues EF, Gama-Rodrigues AC, Correia MEF. Caracterização da fauna edáfica em diferentes coberturas vegetais na região norte fluminense. Sociedade Brasileira de Ciência do Solo 2005; 29(4): 555-564. 10.1590/S0100-06832005000400008

Município de Carlos Barbosa. Perfil da cidade [cited 2019 jul. 15]. Available from: http://www.carlosbarbosa.rs.gov.br/paginas/ perfil-da-cidade/ 1

Nicholls CI, Altieri MA. Projeção e implantação de uma estratégia de manejo de habitats para melhorar o manejo de pragas em agroecossistemas. In: Altieri MA, Nicholls CI, Ponti L, editors. Controle biológico de pragas através do manejo de agroecossistemas. Brasília: MDA; 2007.

Oliveira Filho LCI, Baretta D, Santos JCP. Influência dos processos de recuperação do solo após mineração de carvão sobre a mesofauna edáfica em Lauro Müller, Santa Catarina, Brasil. Biotemas 2014; 27(2): 69-77. 10.5007/2175-7925.2014v27n2p69

Peel MC, Finlayson BL, Mcmahon TA. Updated world map of the Köppen-Geiger climate classification. Hydrology Earth System Sciences 2007; 11: 1633-1644. 10.5194/hess-11-1633-2007
Peñalver-Cruz A, Alvarez-Baca JK, Alfaro-Tapia A, Gontijo L, Lavandero B. Manipulation of Agricultural Habitats to Improve Conservation Biological Control in South America. Neotropical Entomology 2019; 48: 875-898. 10.1007/s13744-019-00725-1

Pompeo PN, Oliveira Filho LCI, Klauberg Filho O, Mafra AL, Barreta CRDM, Barreta D. Diversidade de Coleoptera (Arthropoda: Insecta) e atributos edáficos em sistemas de uso do solo no Planalto Catarinense. Revista Scientia Agraria 2016(a); 17(1): 16-28. 10.5380/rsa.v17i1.46726

Pompeo PN, Santos MAB, Biasi JP, Siqueira SF, Rosa MG, Barreta CRDM, Barreta D. Fauna e sua relação com atributos edáficos em Lages, Santa Catarina - Brasil. Revista Scientia Agraria 2016(b); 17(1): 42-51. doi.org/10.5380/rsa.v17i1.46535

Rocha WO, Dorval A, Peres Filho O, Vaez CA, Ribeiro ES. Formigas (Hymenoptera: Formicidae) Bioindicadoras de Degradação Ambiental em Poxoréu, Mato Grosso, Brasil. Floresta e Ambiente 2015; 22(1): 88-98. 10.1590/2179-8087.0049

Rodrigues DM, Ferreira LO, Silva NR, Guimarães ES, Martins ICF, Oliveira FA. Diversidade de artrópodes da fauna edáfica em agroecossistemas de estabelecimento agrícola familiar na Amazônia Oriental. Revista de Ciências Agrárias 2016; 59(1): 32-38. 10.4322/rca.2097

Rosenberg DM, Danks HV, Lehmkuhl DM. Importance of insects in environmental impact assessment. Environmental Management 1986; 10(6): 773-783. 10.1007/BF01867730

Rusek J. Biodiversity of Collembola and their functional role in the ecosystem. Biodiversity and Conservation 1998; 7(9): 1207-1279. 10.1023/A:1008887817883

Rzeszowski K, Zadrożny P, Nicia P. The effect of soil nutrient gradients on Collembola communities inhabiting typical urban green spaces. Pedobiologia 2017; 64: 15-24. 10.1016/j.pedobi.2017.06.003.

Sabrina T, Hanafi MM, Nor Azwady AA, Mahmud TMM. Earthworm populations and cast properties in the soils of oil palm plantations. Malaysian Journal of Soil Science 2009; 13: 29-42.

Santos DP, Santos GG, Santos IL, Schossler TR, Niva CC, Marchão RL. Caracterização da macrofauna edáfica em sistemas de produção de grãos no Sudoeste do Piauí. Pesquisa Agropecuária Brasileira 2016; 51(9): 1466-1475. 10.1590/s0100-204x2016000900045

Sarlo M. Individual tree species effect on earthworm biomass in a tropical plantation panama. Caribbean Journal of Science 2006; 3: 419-427.

Silva FC, Santana IJ, Martins RD, Lemes NM, Rietjens AR, Lima MLP. Quantificação da microbiota e diversidade ecológica da meso e macrofauna do solo sob diferentes usos no município de Urutaí (região Sudeste Goiano). Multi-Science Journal 2016; 1(4): 12-18. $10.33837 / \mathrm{msj} . v 1 \mathrm{i} 4.112$

Silveira Neto S, Monteiro RC, Zucchi RA, Moraes RCB. Uso da análise faunística de insetos na avaliação do impacto ambiental. Scientia Agricola 1995; 52(1): 9-15. 10.1590/S0103-90161995000100003

Socarrás A. Mesofauna edáfica: indicador biológico de la calidad del suelo. Pastos y Forrajes 2013; 36(1): 5-13.

Souto PC, Souto JS, Miranda JRP, Santos RV, Alves AR. Comunidade microbiana e mesofauna edáficas em solo sob caatinga no semiárido da Paraíba. Revista Brasileira de Ciência do Solo 2008; 32(1): 151-160. 10.1590/S0100-06832008000100015 
Spiller MS, Spiller C, Garlet J. Arthropod bioindicators of environmental quality. Agro@mbiente On-line 2018; 12(1): 41-57. 10.18227/1982-8470ragro.v12i1.4516

Streck EV, Kämpf N, Dalmolin RSD, Klamt E, Nascimento PC, Schneider P, et al. Solos do Rio Grande do Sul. Porto Alegre: UFRGS; 2002.

Thakur MP, Reich PB, Hobbie SE, Stefanski A, Rich R, Rice KE, Eddy WC, Eisenhauer N. Reduced feeding activity of soil detritivores under warmer and drier conditions. Nature Climate Change 2018; 8: 75-78. 10.1038/s41558-017-0032-6

Triplehorn CA, Johnson NF. Estudo dos Insetos. São Paulo: Cengage Learing; 2013.

Wink C, Guedes JVC, Fagundes CK, Rovedder AP. Insetos Edáficos como indicadores da qualidade ambiental. Revista de Ciências Agroveterinárias 2005; 4(1): 60-71. 